\title{
EKSPLORASI DAN IDENTIFIKASI Trichoderma spp. DI UNIVERSITAS TEUKU UMAR
}

\author{
Exploration and Identification of Trichoderma spp. in University of Teuku Umar
}

Lola Adres Yanti ${ }^{1 *}$, Miru Arjo Love Frianos ${ }^{2}$

\author{
${ }^{1)}$ Staf Pengajar pada Program Studi Agroteknologi, Fakultas Pertanian, Universitas Teuku \\ Umar, ${ }^{2)}$ Mahasiswa Program Studi Agroteknologi, Fakultas Pertanian, Universitas Teuku Umar \\ * Corresponding author, e-mail: lolaadresy@yahoo.com; hp : +62-853-12834958.
}

\begin{abstract}
Trichoderma sp. is land microorganisms which saprophyte and naturally strike pathogens and beneficial for the plant. Trichoderma sp. could hinder the growth of some plant diseases such as Rigidoporus lignosus, Fusarium oxysporum, Rhizoctonia solani, Sclerotium rolfsi. In addition, as the ability to control pathogen, Trichoderma sp. give positive effect on rhizosfer, the growth of plants, and plants production. This research aimed to identifying Trichoderma spp. in University of Teuku Umar. The methodology are exploration, isolation, and macroscopic and microscopic observation. The research showed that the similarity of Trichoderma spp. at FKM, FP, FT, and Rectorat were Trichoderma sp. 1 and Trichoderma sp. 2. On UF of peat and alluvial land only had Trichoderma sp. 1.
\end{abstract}

Keywords: Different location, exploration and identification, Trichoderma spp.

\section{PENDAHULUAN}

Cendawan Trichoderma sp. merupakan mikroorganisme tanah bersifat saprofit yang secara alami menyerang cendawan patogen dan bersifat menguntungkan bagi tanaman. Cendawan Trichoderma sp. merupakan salah satu jenis cendawan yang banyak dijumpai hampir pada semua jenis tanah dan pada berbagai habitat yang merupakan salah satu jenis cendawan yang dapat dimanfaatkan sebagai agens hayati pengendali patogen tanah. Spesies Trichoderma sp. di samping sebagai organisme pengurai, dapat pula berfungsi sebagai agens hayati (Wahyuno et al. 2009).

Trichoderma sp. dapat menghambat pertumbuhan beberapa jamur penyebab penyakit pada tanaman antara lain Rigidiforus lignosus, Fusarium oxysporum, Rizoctonia solani, Sclerotium rolfsi. Di samping kemampuan sebagai pengendali hayati, Trichoderma sp. memberikan pengaruh positif terhadap perakaran tanaman, pertumbuhan tanaman, hasil produksi tanaman. Sifat ini menandakan bahwa juga Trichoderma sp. berperan sebagai Plant Growth Enhancer (Herlina dan Pramesti 2009).

Menurut Sutarini et al. (2015), aplikasi Trichoderma sp. pada kompos dan pupuk kandang (pupuk kandang sapi dan ayam) mampu menekan penyakit layu fusarium di lapangan dengan persentase penyakit terendah pada perlakuan P3 (pupuk kotoran sapi + Trichoderma sp. + tanah $+F$. oxysporum f.sp. capsici) dan $\mathrm{P} 4$ (pupuk kotoran ayam + Trichoderma sp. + tanah $+F$. oxysporum f.sp. capsici) sebesar $4.0 \%$ pada pengamatan 16 MST dibandingkan dengan kontrol $48.0 \%$.

Menurut Hidayat et al. (2014), perendaman benih dan penyemprotan 
tanaman padi menggunakan agensia hayati Trichoderma sp. mampu mengurangi keparahan penyakit blas. Hasil pengamatan terhadap keparahan penyakit pada $7,8,9$, dan 10 minggu setelah pindah tanam (MSPT) berturut-turut adalah $0.2 \%, 0.4 \%$, $0.8 \%$ dan $1 \%$ dibandingkan dengan kontrol (tanpa Trichoderma sp.) yaitu 0.6\%, 3\%, $11.2 \%$ dan $21 \%$.

Menurut Damanik et al. (2013), kombinasi Trichoderma sp. dengan $P$. fluorescens (T2) adalah agen hayati yang efektif menekan perkembangan Xanthomonas oryzae pv. oryzae yaitu sebesar $4.74 \%$, disusul dengan $P$. fluorescens (T1) sebesar $10.26 \%$ sedangkan T0 (Kontrol) kurang efektif dengan intensitas serangan yang tertinggi yaitu sebesar $23.14 \%$.

Berdasarkan uraian di atas maka penting dilakukan penelitian mengenai eksplorasi dan identifikasi Trichoderma spp. di Universitas Teuku Umar. Penelitian ini bertujuan untuk mengidentifikasi Trichoderma spp. di lingkungan Universitas Teuku Umar.

\section{BAHAN DAN METODE PENELITIAN}

\section{Waktu dan Tempat}

Penelitian ini dilakukan mulai bulan Februari 2018 sampai dengan selesai. Tempat penelitian antara lain, Laboratorium Umum Fakultas Pertanian dan Laboratorium Terpadu UTU, serta Laboratorium Pengamatan Hama Penyakit Tanaman Pangan Hortikultura di Pulo ie, Nagan Raya.

\section{Bahan dan Alat}

Bahan yang digunakan dalam penelitian meliputi: kelapa, media PDA, aquades, kapas, aluminium foil, plastic wrap dan lain-lain. Peralatan digunakan dalam penelitian meliputi: autoclave, kabinet laminar air flow, corebore, mikroskop, kaca preparat, cover glass dan lain-lain.

\section{Pelaksanaan Penelitian}

Eksplorasi Trichoderma spp.

Pada kegiatan eksplorasi,

Trichoderma spp. dijerap menggunakan kelapa yang ditanam di bawah tegakan pohon sehat. Kegiatan penjerapan ini dilakukan selama 3 hari. Setelah 3 hari, Trichoderma sp. dapat langsung dipanen. Trichoderma sp. berwarna hijau tua dan hijau kekuningan.

Kegiatan penjerapan ini dilakukan pada Fakultas Pertanian, Fakultas Kesehatan Masyarakat, Fakultas Teknik, University Farm tanah gambut, University Farm tanah alluvial dan rektorat.

\section{Isolasi Trichoderma spp.}

Trichoderma spp. hasil penjerapan ditanam di media PDA menggunakan corebore berdiameter $5 \mathrm{~mm}$, kemudian diinkubasi pada suhu $25{ }^{\circ} \mathrm{C}$ di dalam laminar air flow hingga miselium memenuhi cawan.

Pengamatan Makroskopis dan Mikroskopis Isolat Trichoderma spp.

Pengamatan dilakukan berdasarkan karakteristik morfologi secara makroskopis dan mikroskopis meliputi, warna, tekstur, topografi koloni, dan diameter pertumbuhan, serta ukuran dan bentuk hifa. Identifikasi dilakukan menggunakan buku kunci identifikasi untuk genus imperfect fungi (Barnet dan Hunter 1998).

\section{Analisis Data}

Data bersifat deskriptif dan disajikan dalam bentuk gambar dan tabel.

\section{HASIL DAN PEMBAHASAN}

\section{Hasil}

Hasil penelitian menunjukkan bahwa pada berbagai tempat (Fakultas) di Lingkungan Kampus UTU terdapat Trichoderma spp.

Tabel 1 menunjukkan kode isolat dan vegetasi asal Trichoderma spp. di 
berbagai tempat di Lingkungan Kampus

UTU.

Tabel 1. Trichoderma spp. asal lingkungan kampus UTU

\begin{tabular}{|c|c|c|c|}
\hline No & Kode Isolat & Lokasi & Vegetasi \\
\hline 1 & $\begin{array}{l}\text { Trichoderma sp. } 1 ; \\
\text { Trichoderma sp. } 2\end{array}$ & FKM & Pohon bak manee (Vitex pinnata) \\
\hline 2 & $\begin{array}{l}\text { Trichoderma sp. } 1 \text {; } \\
\text { Trichoderma sp. } 2\end{array}$ & FP & Pohon bak manee (Vitex pinnata) \\
\hline 3 & Trichoderma sp. 1 & UF Tanah Gambut & Pisang \\
\hline 4 & Trichoderma sp. 1 & UF Tanah Aluvial & Jagung \\
\hline 5 & $\begin{array}{l}\text { Trichoderma sp. } 1 \text {; } \\
\text { Trichoderma sp. } 2\end{array}$ & FT & Pohon senggani (Malastoma candidom) \\
\hline 6 & $\begin{array}{l}\text { Trichoderma sp. } 1 \text {; } \\
\text { Trichoderma sp. } 2\end{array}$ & Rektorat & Pohon trembesi \\
\hline
\end{tabular}

Pada keenam lokasi di dalam Identifikasi dilakukan secara makroskopis lingkungan Universitas Teuku Umar, dan mikroskopis. Gambar 1 menunjukkan ditemukan spesies Trichoderma spp. penampakan makroskopis Trichoderma spp. yang diperoleh.

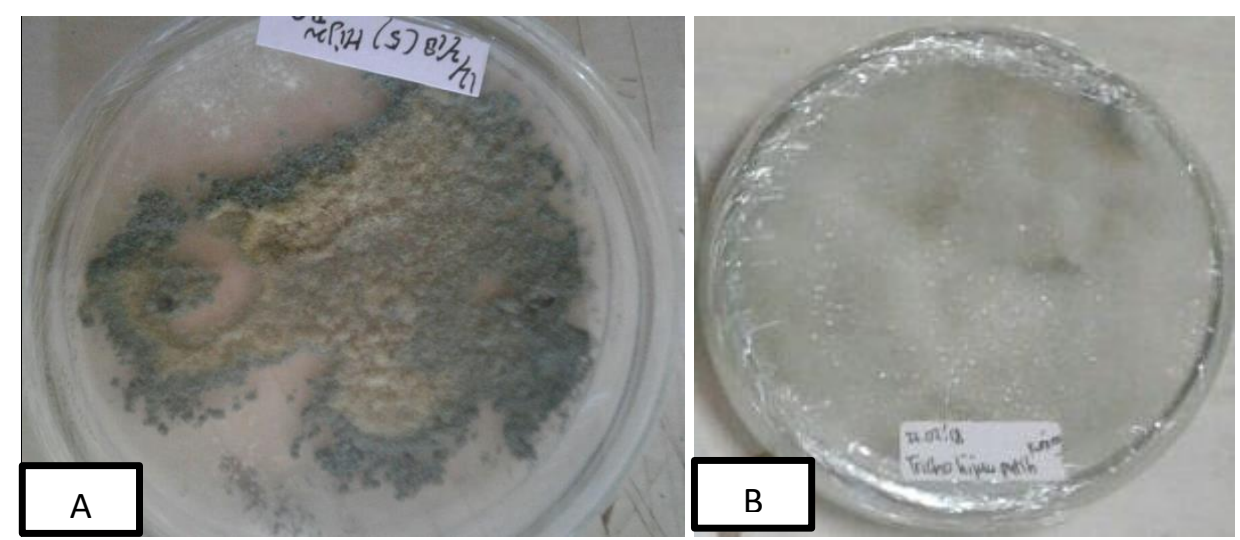

Gambar 1. Penampakan makroskopis Trichoderma spp. : (A) Trichoderma sp. 1; (B) Trichoderma sp. 2

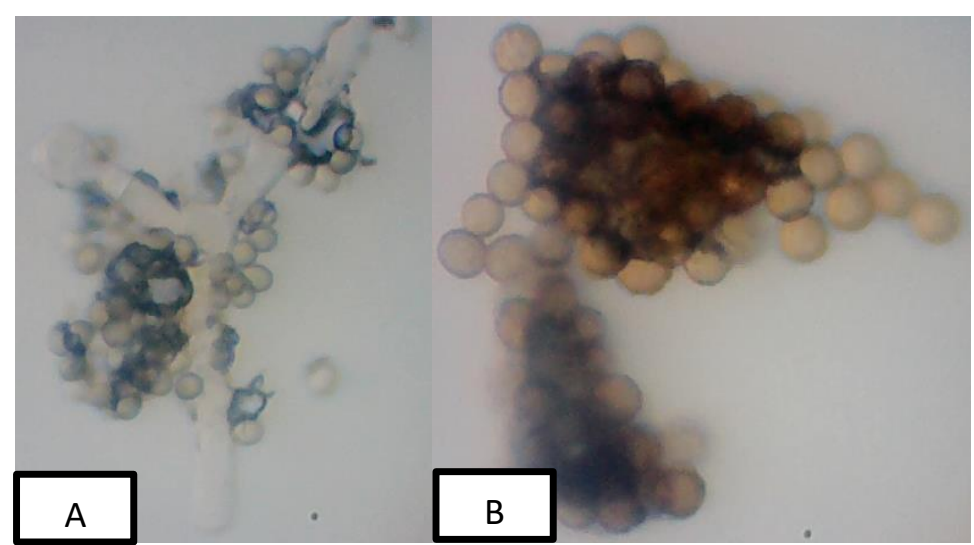

Gambar 2. Penampakan mikroskopis Trichoderma sp. 1 : (A) konidiofor Trichoderma sp. 1; (B) konidia Trichoderma sp. 1 


\section{Pembahasan}

Tabel 1 menunjukkan bahwa terdapat 2 jenis Trichoderma sp. di lokasi FKM, FP, FT dan Rektorat, namun di lokasi UF baik tanah gambut maupun tanah alluvial hanya terdapat satu jenis Trichoderma sp. Hal ini diduga karena Trichoderma sp. merupakan cendawan tanah yang selalu ada di berbagai macam tanah. Sesuai dengan pernyataan Wahyuno et al. (2009) bahwa cendawan Trichoderma sp. merupakan salah satu jenis cendawan yang banyak dijumpai hampir pada semua jenis tanah dan pada berbagai habitat.

Trichoderma sp. yang diperoleh diduga berasal dari jenis yang berbeda, namun tidak bisa diidentifikasi secara mikroskopis karena konidiofor yang merupakan ciri khas fungi ini tidak tampak jelas. Sehingga identifikasi dilakukan hanya dengan identifikasi secara makroskopis. Trichoderma sp. 1 memiliki warna koloni hijau tua yang diawali dengan warna putih, putih agak kehijauan, hijau muda, hijau dan hijau tua setelah umur 7 hari. Namun Trichoderma sp. 2 memiliki warna koloni hijau muda yang diawali dengan warna putih, putih agak kehijauan, hijau muda setelah umur 7 hari. Sesuai dengan Gusnawaty et al. (2014), bahwa dari 11 isolat Trichoderma spp. indigenos Sulawesi Tenggara yang dikarakterisasi berdasarkan morfologinya terjadi perkembangan warna koloni yang berbeda dari hari ke-1 sampai hari ke-7. Perkembangan warna koloni diawali dengan warna putih, putih agak kehijauan, hijau muda, hijau dan hijau tua setelah umur 7 hari, namun pada isolat ASL warna koloni yang terlihat dari hari ke-3 hingga ke-7 terdapat warna kekuningan, sedangkan pada isolat LKP warna kekuningan hanya terlihat sampai hari ke5 .

Karakterisasi secara mikroskopis yakni bentuk konidiofor dan konidia (Gambar 2) menggunakan buku identifikasi Watanabe (2002). Gambar 2 menunjukkan bahwa isolat tersebut memiliki bentuk konidiofor yang dikembangkan pada struktur bantal berbentuk tegak, bercabang yang tersusun vertikal. Fialid pendek dan tebal, konidia hijau muda, berdinding halus dan berbentuk oval. Konidia hijau dan berbentuk oval. Semua spesies tersebut memiliki bentuk koloni yang sama yaitu bulat. Hal ini didukung oleh pernyataan Rifai (1996) bahwa sebagian besar anggota dari genus Trichoderma membentuk koloni yang mempunyai warna yang berbeda dan membentuk koloni dengan zona lingkaran yang terlihat dalam cahaya.

\section{KESIMPULAN}

Terdapat kesamaan jenis Trichoderma sp. di lokasi FKM, FP, FT dan Rektorat yaitu Trichoderma sp. 1 dan Trichoderma sp. 2. Pada lokasi UF baik di tanah gambut maupun alluvial, hanya terdapat Trichoderma sp. 1.

\section{DAFTAR PUSTAKA}

Barnet HL, Hunter BB. 1998. Illustrated Genera of Imperfect Fungi. Minessota (US): APS Press. 4th edition Bayu

Damanik S, Pinem MI, Pengestiningsih Y. 2013. Uji efikasi agens hayati terhadap penyakit hawar daun bakteri (Xanthomonas oryzae Pv. Oryzae) pada beberapa varietas padi sawah (Oryza sativa). Jurnal Online Agroekoteknologi. 1(4)

Gusnawaty HS, Taufik M, Triana L, Asniah. 2014. Karakterisasi morfologis Trichoderma spp. indigenus Sulawesi Tenggara. Jurnal Agroteknos. 4(2):87-93

Herlina L, Pramesti D. 2009. Penggunaan Kompos Aktif Trichoderma sp. dalam Meningkatkan Pertumbuhan 
Tanaman Cabai. Semarang(ID): Universitas Negeri Semarang

Hidayat YS, Nurdin M, Suskandini RD. 2014. Penggunaan Trichoderma sp. sebagai agensia pengendalian terhadap Pyricularia oryzae Cav. penyebab blas pada padi. J. Agrotek Tropika. 2(3): 414-419

Sutarini NLW, Sumiartha K, Suniti NW, Sudiarta P, Wirya GNAS, Utama MS. 2015. Pengendalian penyakit layu fusarium pada tanaman cabai besar (Capsicum annuum L.) dengan kompos dan pupuk kandang yang dikombinasikan dengan Trichoderma sp. di rumah kaca. E-
Jurnal Agroekoteknologi Tropika. 4(2).http://ojs.unud.ac.id/index.php/ JAT

Wahyuno D, Manohara D, Mulya K. 2009. Peranan bahan organik pada pertumbuhan dan daya antagonisme Trichoderma harzianum dan pengaruhnya terhadap $P$. capsici. pada tanaman lada. Jurnal Fitopatologi Indonesia. 7: 76-82

Watanabe T. 2002. Pictorial Atlas of Soil and Seed Fungi Morphologies of Cultured Fungi and Key to Species. USA: CRC Press LLC 